\title{
Kadar Bantahan Atas Khilafah
}

Shohibul Anshor Siregar

|Dalam perkembangan Indonesia kontemporer banyak pihak melihat alasan yang tepat memusuhi ide khilafah|Tetapi tidaklah dengan permusuhan itu sejarah bisa diubah| Juga tak akan mampu menghilangkan kebenaran meski dengan memojokkan pencari kebenaran itu sendiri, misalnya dengan pendiskreditannya sebagai radikall

Belakangan ini Indonesia resah oleh ide khilafah yang di antara banyak fakta untuk itu ialah pembubaran Hizbuttahrir Indonesia (HTI). Tetapi HTI bukanlah segalanya dalam catatan perjuangan khilafah. Surat kabar Bandera Islam Tahun I No 13 yang mengupas tentang khilafah tanggal 25 Desember 1924 mencatat fakta penting (Septian A.W., 2013).

Dikatakan, bahwa Desember 1924 di Surabaya diadakan Kongres Al-Islam Luar Biasa dengan peserta 68 (enam puluh delapan) organisasi. Para ulama dan ribuan umat Islam hadir dan menyepakati sebuah rumusan khilafah yang baru: Pertama, agar dibentuk suatu Majelis Khilafah yang melaksanakan kekuasaan dan kewajiban khalifah atas dasar hukum-hukum Al-Qur'an dan Hadits.

Kedua, Kepala Majelis mengatur, menjaga, dan mengupayakan terlaksananya keputusan-keputusan Majelis. Ketiga, Kepala Majelis dipilih oleh Majelis berdasarkan Shari'ah yang disetujui atasnya dalam permusyawaratan khilafah kemudian pemilihan tersebut diumumkan agar mendapat pengakuan dari seluruh umat Islam di dunia. Keempat, Majelis Khilafah mengupayakan persamaan faham dan peraturan bagi segala perkara hukum Islam. Kelima, Majelis Khilafah hendaklah berada di Mekkah. Keenam, tentang biaya untuk Majelis Khilafah bersama-sama perlu ditemukan kesepakatan dengan umat Islam yang lain atas hal ini.

Penelitian Septian A.W. (2013) yang mengandalkan keterangan Surat Kabar Bandera Islam ini menemukan semangat dan perjuangan umat Islam Indonesia dalam mewujudkan negara Islam. Menurutnya perjuangan penegakan Khilafah Islamiyah segera setelah keruntuhan Khilafah Turki Usmani, telah menjadi faktor keresahan penting yang mendorong sejumlah tokoh berpengaruh beserta umat Islam untuk terlibat memperjuangkan penegakan kembali Khilafah Islam seperti H.O.S. Tjokroaminoto, K.H. Agus Salim, K.H. Fakhrudin dan K.H. Mas Mansur.

Secara kronologis tampaknya semua berawal dari kekalahan Turki Usmani (Ottoman) dalam Perang Dunia disusul munculnya Mustafa Kemal Pasha yang pada tahun 1922 mengubah pemerintahan sistem khilafah. Awalnya jabatan khalifah tetap dipertahankan, tetapi dengan pemerosotan yang membuatnya hanya mirip macan kertas belaka sebab tanpa kekuasaan duniawi. Khawatir atas khalifah saat itu, Abdul Majid, maka pada tanggal 3 Maret 1924, melalui Majelis Nasional Turki, Mustafa Kemal Pasha secara resmi menghapus untuk selamanya kekhilafahan Turki Usmani yang berusia ratusan tahun itu.

Peristiwa ini beroleh reaksi keras dari dunia Islam. Pertemuan ulama Al-Azhar di Kairo (1924) meminta jabatan khalifah Abdul Majid yang sudah dimakzulkan dan bahkan diusir dari Turki dipulihkan kembali. Para ulama yakin eksistensi khalifah adalah wajib untuk memimpin umat Islam. Sebuah rekomendasi lain berisikan penjadwalan pertemuan perwakilan dunia Islam (Maret 1925) untuk menetapkan khalifah yang baru di Kairo. Tetapi tak lama berselang (April 1924), penguasa Mekkah saat itu, Syarif Husein, mendeklarasikan diri sebagai khalifah yang baru meski tak beroleh dukungan dan Syarif Husein sendiri malah dianggap antek Inggris yang diposisikan sebagai perpanjangan tangan musuh. 
Di Garut, pada bulan Mei 1924, tokoh-tokoh pergerakan Islam dan ulama berkumpul pada Kongres Al-Islam membahas persoalan khilafah. Ketika itu H. Agus Salim mendesak untuk terlibat mencari solusi masalah kekhalifahan Islam. Kemudian pada tanggal 4-5 Oktober 1924 para pemimpin Sarekat Islam, Muhammadiyah dan Al-Irsyad serta ulama-ulama besar lainnya, baik dari kalangan Arab mau pun Jawa, berkumpul di Madrasah Tarbiatoel Aitam dan di sana Tjokroaminoto menegaskan perlunya umat Islam tak hanya memiliki seorang khalifah, tetapi juga peran aktif untuk kepentingan khilafah. Tiga kesepakatan yang diperoleh ialah khilafah wajib ada, terbentuknya Komite Khilafah, dan berpartisipasi dalam Kongres Kairo.

Septian A.W. tidak sendirian dalam penelusuran fakta-fakta ini. Konfirmasi silang kesimpulannya bertemu dengan data Deliar Noer dalam disertasinya berjudul The Modernist Muslim Movement in Indonesia 1900-1942 (Cornell University, 1962). Juga pada disertasi Aqib Suminto Politik Islam Hindia Belanda (IAIN Jakarta, 1985), dan Martin van Bruinessen dalam Muslim of Dutch East Indies and The Caliphate Question (Studia Islamika, 1995). Perjuangan mendirikan khilafah di Indonesia adalah fakta sejarah yang nanti pada saat perumusan dasar negara dan UUD Negara semuanya terasa beroleh konfirmasi meyakinkan.

Dengan tetap menghargai ikhtilaf para ahli, dalil-dalil tentang negara dalam al-Qur'an bukanlah sesuatu yang langka. Selain ayat-ayat yang belakangan sangat populer di Indonesia soal pemimpin (Al-Maidah: 51 dan seterusnya), terdapat keterangan cukup lugas dan insha Allah nyaris tidak bersifat multitafsir. "Sesungguhnya Allah menyuruh kalian menyampaikan amanat kepada yang berhak menerimanya, dan (menyuruh kalian) apabila menetapkan hukum di antara manusia supaya kalian menetapkan dengan adil. Sesungguhnya Allah memberi pengajaran yang sebaik-baiknya kepada kalian. Sesungguhnya Allah adalah Maha Mendengar lagi Maha Melihat. Hai orang-orang yang beriman, taatilah Allah, taatilah Rasul-(Nya) dan ulil-amri di antara kalian." (An-Nisa`: 58-59).

Kedua ayat itu mencakup seruan kepada ulil-amri (penguasa) antara lain agar menetapkan hukum dengan adil; sekaligus kepada rakyat agar taat bersyarat kepada ulil-amri (ketaatan kepada Allah dan Rasul-Nya). Di atas segalanya silang pendapat hanya akan diselesaikan menurut Al-Qur’an dan Sunnah.

Kiranya rujukan utama dan terpenting pembumian konsepsi khilafah tentu saja harus dipetik dari rasulullah Muhammad SAW yang telah mempraktikkannya melalui pembentukan negara Madinah. Semua kerajaan Islam dalam bentuk apa pun dan dengan penamaan apa pun pastilah merujuk pada prototype ini. Pula, dari keterandalan gagasan, harus diakui banyak pelajaran yang dipetik dunia moderen dari al-Dustûr al-Madînah (Konstitusi Madinah) ketika mereka berusaha melakukan pembentukan negara. Konstitusi berisi 47 pasal itu setidaknya memiliki karakteristik kuat dalam beberapa kategori, di antaranya:

Pertama, pengaturan harmoni dalam fakta pluralitas. Madinah memang berbilang puak, leluhur, budaya dan juga agama dan mereka dinamis saja tak terkendala sedemikian rupa di bawah pengaturan Konstitusi Madinah.

Kedua, perikatan yang kuat dalam wadah bersama satu negara di bawah penguasa Muslim (Nabi Muhammad) melalui persaudaraan. Konstitusi Madinah mengorganisasikan Muslim dan non-Muslim dalam perikatatan besar itu.

Ketiga, kebebasan. Semua pemeluk agama dijamin kebebasannya oleh negara untuk menjalankan hal-hal yang terbaik menurut agamanya tanpa merasa dibayang-bayangi rasa tak nyaman, apalagi ketakutan. 
Keempat, kesetaraan. Bahwa semua warga dipandang setara oleh konstitusi. Pasal terakhirnya sendiri, 47, konstitusi ini kurang lebih menegaskan demikian: "Sesungguhnya piagam ini tidak membela orang zalim dan khianat. Orang yang keluar (bepergian) aman, dan orang berada di Madinah aman, kecuali orang yang zalim dan khianat. Allah adalah penjamin orang yang berbuat baik dan takwa, dan Muhammad Rasulullah SAW".

Bagaimana membantah konsepsi khilafah dengan semua fakta itu meskipun upaya pencarian jejak untuk memeroleh data konstruk serta keberagamannya tetap sangat diperlukan? Upaya Mustafa Hilmi dan Nidhâm cukup membantu. Dalam Al-Khilâfah Bayn Ahl Al-Sunnah Wa Al-Syi'ah keduanya (1988) menemukan berbagai sumber Islam yang memberi sejumlah variasi penamaan. Misalnya terminologi daulah yang dapat secera sederhana disebut sebagai negara, bani yang merujuk kepada pengertian dinasti, hukmiyyah yang menerangkan hal-ihwal pemerintahan, sulthan untuk memaksudkan bentuk kerajaan, dan khilafah sendiri yang menerangkan konstruk negara, dan terminologi imâmah yang jika dimaknai sebagai kepemimpinan malah tak hanya mencakup kekhalifahan atau negara.

Apa pun sebutan yang menunjukkan perbedaan pemahaman dan penerapan negara Islam itu, bagi Ahmad Zaki Badawi (A dictionary of the social sciences,1993) semuanya tiba pada 3 gradasi model kekhalifahan: al-daulah al-ittihâdiyyah (negara federal), al-daulah al-qannniyyah (negara hukum) dan al-daulah ar-rafâhiyyah (negara kesejahteraan).

Mungkin masalah kekhalifahan adalah salah satu persoalan paling kaya sekaligus paling menegangkan dalam sejarah Islam pasca meninggalnya rasulullah Muhammad SAW, terlebih karena ia memiliki sensitifitas kaitan dengan dunia non-muslim. Khususnya selama abad ke-20, seiring kemerosotan kerajaan-kerajaan Islam yang terkait dengan aspek-aspek sangat luas seperti adopsi demokrasi dan masalah etnis dan agama di ranah publik serta keserta-mertaan sekularisasi yang melanda, telah lahir berbagai sikap yang gagal menapak ke jenjang ijtima. Begitu kuat keinginan memadukan Islam dan negara bagi mujtahid tertentu dan pengikutnya dengan argumen bahwa Islam memang menyediakan sistem sosial sempurna merujuk Al-Qur'an dan Sunnah. Kelompok tekstualis seperti ini yakin umat Islam berada dalam posisi paling benar mengikuti tradisi politik Islam klasik dengan seruan ke Al-Qur'an dan Sunnah secara totalitas.

Di seberangnya tak kurang gesit pihak yang memosisikan Al-Qur'an dan Sunnah sebagai sumber ide yang mencirikan ijtihad terbuka lebar untuk menjawab tuntutan kontekstual sembari menepis pemikiran taqlid. Tak kurang pentingnya dalam catatan sejarah peran yang dimainkan kalangan yang secara sadar ingin memisahkan agama dan negara, sebagaimana sepak terjang Kemal Attaturk (Turki), 'Ali Abd Raziq (Mesir) dan Suhatsjah (Soekarno, Hatta dan Sjahrir) di Indonesia.

Dalam perkembangan Indonesia kontemporer banyak pihak melihat alasan yang tepat memusuhi ide khilafah. Tetapi tidaklah dengan permusuhan itu sejarah bisa diubah. Juga tak akan mampu menghilangkan kebenaran meski dengan memojokkan pencari kebenaran itu sendiri, misalnya dengan pendiskreditannya sebagai radikal.

Muncul pertanyaan serius ketika belum lama ini ada kejutan oleh khabar simpang siur dokumen BPUPKI dan PPKI. Catatlah keluhan AB Kusuma: "Kalau pada masa Orde Baru mungkin bisa dimaklumi ketika masih terjadi de-sukarnoisasi. Tetapi sekarang sudah era reformasi. "DeSukarnoisasi" sudah dicabut. Sekarang sudah ada UU Keterbukaan Informasi Publik. Tapi arsip primer BPUPKI dan PPKI masih tertutup," (Bicara Buku Bersama Wakil Rakyat' di Press Room, Kompleks Parlemen, Jakarta, Senin, 16/10).

Di sana pastilah ternukil risalah lengkap tentang sebagai negara apa Indonesia akan dimerdekakan. Indikasi awal tentu kalimat yang dihapus "kewajiban menjalankan syariat Islam bagi pemeluk- 
pemeluknya". Tak berhenti pertanyaan tentang substansi jenis negara apa yang sepadan dengan kalimat yang dihapus. Tetapi juga model diplomasi dan etika pengambilan keputusan apa yang secara sepihak berhak atas penghormatan dilihat dari sudut nilai permusyawaratan.

Kini telah terlanjur pelabelan radikal terhadap penggugat distorsi sejarah yang melihat andil dan sepak terjang umat Islam tereduksi dan bahkan disimpangkan. Itu jelas tidak adil, dan para sejawat yang berminat dalam studi ini seperti Prof.Dr Rasyidin, MA dan Prof Dr Hasnah Nasution, MA dari UINSU, pastilah merasa amat terganggu secara akademik.

Dari mana dan untuk kepentingan siapakah tuduhan radikal ini muncul? Sebuah perbincangan yang diberi judul Penyebaran Global Islam Wahhabi: Seberapa Besar Ancamannya? diselenggarakan pada tanggal 3 Mei 2005 di Pew Research Center, Washington, D.C. Dari sana sebuah jawaban representatif dan tipikal Barat ditemukan. Paul Marshall, Senior Fellow, Pusat Kebebasan Beragama, Freedom House, R. James Woolsey, Mantan Direktur Central Intelligence; Wakil Presiden, Booz Allen Hamilton dan John Voll, Profesor Sejarah dan Direktur Islam, Pusat Pemahaman Muslim-Kristen, Universitas Georgetown, yang berbicara pada forum ini dengan jelas menunjukkan kesewenangwenangan merencanakan apa yang mereka inginkan untuk dunia Islam. Mereka mengkonstruk Islam yang tak mereka sukai sebagai musuh. 